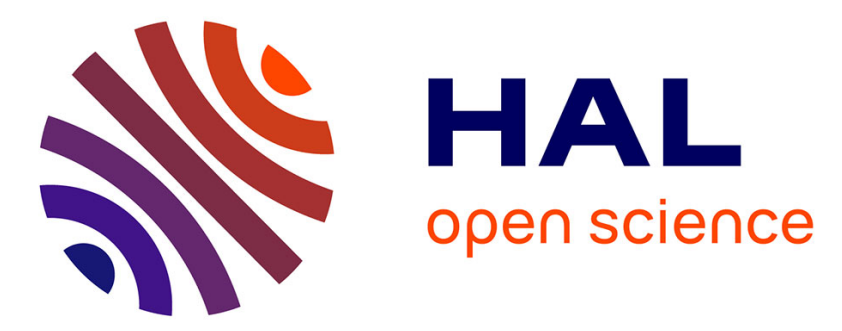

\title{
Cross-linguistic influence in language creation: Assessing the role of the Gbe languages in the formation of the Creoles of Suriname
}

\author{
James; Essegbey, Bettina Migge, Donald Winford
}

\section{To cite this version:}

James; Essegbey, Bettina Migge, Donald Winford. Cross-linguistic influence in language creation: Assessing the role of the Gbe languages in the formation of the Creoles of Suriname. Lingua, 2013, 129 (7), pp.1-8. 10.1016/j.lingua.2013.02.005 . hal-01495064

\author{
HAL Id: hal-01495064 \\ https://hal.science/hal-01495064
}

Submitted on 28 Mar 2017

HAL is a multi-disciplinary open access archive for the deposit and dissemination of scientific research documents, whether they are published or not. The documents may come from teaching and research institutions in France or abroad, or from public or private research centers.
L'archive ouverte pluridisciplinaire HAL, est destinée au dépôt et à la diffusion de documents scientifiques de niveau recherche, publiés ou non, émanant des établissements d'enseignement et de recherche français ou étrangers, des laboratoires publics ou privés.

$$
\text { Copyright }
$$




\section{Research Repository UCD}

Provided by the author(s) and University College Dublin Library in accordance with publisher policies. Please cite the published version when available.

\begin{tabular}{|c|c|}
\hline Title & $\begin{array}{l}\text { Cross-linguistic influence in language creation: Assessing the } \\
\text { role of the Gbe languages in the formation of the Creoles of } \\
\text { Suriname }\end{array}$ \\
\hline Author(s) & Essegbey, James; Migge, Bettina; Winford, Donald \\
\hline $\begin{array}{l}\text { Publication } \\
\text { date }\end{array}$ & 2013-03-21 \\
\hline $\begin{array}{l}\text { Publication } \\
\text { information }\end{array}$ & Lingua, 129 (May 2013): 1-8 \\
\hline Publisher & Elsevier \\
\hline $\begin{array}{l}\text { Item } \\
\text { record/more } \\
\text { information }\end{array}$ & http://hdl.handle.net/10197/5847 \\
\hline $\begin{array}{l}\text { Publisher's } \\
\text { statement }\end{array}$ & $\begin{array}{l}\text { This is the author's version of a work that was accepted for } \\
\text { publication in Lingua. Changes resulting from the publishing } \\
\text { process, such as peer review, editing, corrections, structural } \\
\text { formatting, and other quality control mechanisms may not be } \\
\text { reflected in this document. Changes may have been made to } \\
\text { this work since it was submitted for publication. A definitive } \\
\text { version was subsequently published in Lingua (VOL } 129 \text {, } \\
\text { ISSUE 2013, (2013)) DOI: } 10.1016 / \text { j.lingua.2013.02.005 }\end{array}$ \\
\hline $\begin{array}{l}\text { Publisher's } \\
\text { version (DOI) }\end{array}$ & http://dx.doi.org/10.1016/j.lingua.2013.02.005 \\
\hline Notes & $\begin{array}{l}\text { First presented at a workshop entitled "A comparative } \\
\text { Syntactic Approach to the Historical Development of the } \\
\text { Creoles of Suriname", Ohio State University, May } 2010\end{array}$ \\
\hline
\end{tabular}

Downloaded 2017-03-21T20:15:12Z

The UCD community has made this article openly available. Please share how this access benefits you. Your story matters! (@ucd_oa) 
Some rights reserved. For more information, please see the item record link above.

(c) $(\mathrm{B})(\mathrm{F}$ 
Cross-linguistic Influence in Language Creation: Assessing the Role of the Gbe Languages in the Formation of the Creoles of Suriname.

Introduction ${ }^{1}$

James Essegbey (University of Florida), Bettina Migge (University College Dublin), Donald

Winford (the Ohio State University)

\section{Introduction}

This special issue of Lingua explores the role of language contact and substrate influence in the formation of the Surinamese creoles, as well as the issues they raise for theories of contactinduced change and creole formation in particular. The seven related creole languages spoken in Suriname - Sranan Tongo, Aluku or Boni, Kwinti, Ndyuka or Okanisi, Pamaka, Matawai, and Saamaka - are a unique test case for such exploration. ${ }^{2}$ Sociohistorical (e.g. Arends, 2002; Hoogbergen, 1990a\&b; Thoden van Velzen and Hoogbergen, 2011) and linguistic evidence suggest that they all had their origins in the early creole that emerged on the plantations of Suriname in the late 17th to early 18th century, that is, roughly between 1660 and 1720 . Modern Sranan is a direct continuation of this early contact language while the other creoles, generally referred to as Maroon creoles, split off from it as a result of their founders' flight from the Surinamese plantations at different periods of time. Their common origin is reflected in the similarities they manifest at all levels of linguistic structure, from phonology to morphology, syntax, and lexical semantics (see Winford and Migge, 2004; Smith and Haabo, 2004 for an overview). Most of these similarities can be attributed to a shared input from the West African

1 The papers in this volume were first presented at a workshop titled "A comparative Syntactic Approach to the Historical Development of the Creoles of Suriname", which was held at the Ohio State University in May 2010. The workshop was funded jointly by a Department of Linguistics Targeted Investment Initiative Grant of $\$ 4,900.00$ and a College of Humanities Grant of $\$ 5,000.00$, with additional support from various departments in the College of Humanities at the Ohio State University. We wish to express our gratitude to all concerned for making the workshop and this volume possible.

2 Sranan Tongo, sometimes also written as Sranantongo, is often also referred to as Sranan. There are also different versions of the same name for some of the Maroon languages which continue to coexist. Pamaka is also sometimes written as Paramacca(a)n, Paramacca, Paramaka or Paamka and Saamaka (or Saamáka) is also spelled as Saramacca(a)n, Saramaka. We generally use the ethnonym; however, different authors in this volume have made different choices. 
substrate languages that were part of the primary input to the formation of these creoles. This volume is concerned primarily with such substrate influence.

Although Haitian Creole (Lefebvre, 1998) and the Pacific creoles including Hawai'an Creole (Siegel, 1999, 2000, 2010) have also figured in research on substrate influence in creole genesis, the Surinamese creoles have attracted the most attention in the literature to date. They are among the most "radical" or divergent of English-related creoles in that their grammars depart significantly from that of English, their primary lexifier. They developed in contexts of natural second language acquisition that involved highly reduced access to native English input and encouraged reliance on the first languages of their creators, enslaved Africans. To a large extent, both the similarities across the creoles, and their high degree of divergence from the language that provided most of their lexicon are due to significant input from the West African languages spoken by the slaves. However, other factors have also played a role. The present volume seeks to provide further answers to questions regarding the interplay between English (and Dutch) superstrate input, West African substrate influence and, where relevant, later internally and externally motivated changes, in the creation and later development of these creoles.

\section{A brief historical overview}

The colony of Suriname was founded in 1651 as an English colony but came under Dutch control in 1667 as the result of the second Anglo-Dutch war. ${ }^{3}$ In this early period, English planters introduced the plantation system in the coastal areas, and introduced slaves most of whom had already lived in other colonies such as Barbados. During the English period and the early Dutch reign the population was characterized by relatively small ratios of Africans to Europeans, and earlier slaves to newly imported slaves. The ratio of Africans to Europeans remained relatively constant between $2: 1$ and 3:1 and the ratio between pre-existing slaves and newly imported slaves was less than 1:2 (Arends, 1995). By 1667, there were about 1,500 Europeans (mostly English), and about two to three thousand Africans. The early European population consisted mainly of speakers of dialects of English and, after 1665, also of speakers

3 To be precise, it came under the control of the Province of Zealand (Arends, 2002). 
of Portuguese and Spanish. ${ }^{4}$ The latter were of Jewish background and came to Suriname from North East Brazil (via French Guyana), from Essequibo (Guyana), and from Europe (Livorno, Amsterdam) (Arends, 1999:199). After the Dutch take-over, English settlers and their slaves were forced to leave Suriname. The number of English settlers slowly declined to only about 38 in 1689 (Voorhoeve and Lichtfeld, 1975:2-3). They were replaced by speakers of different European languages such as Dutch, Swedish, French etc. However, it seems that several of the English planters returned to Suriname after they had initially been forced to leave. They constituted an important segment of the European population well into the 1690s (Arends, 2002). According to Postma (1990:185), there were roughly 379 Europeans and 4,618 Africans in the colony in 1695.

The earliest Sranan texts available to us date back to the late $17^{\text {th }}$ century (van den Berg, 2000); hence we can assume that the early plantation creole emerged some time during the period $1651-1700$, most likely between $1670-1700$, and was probably well established by the time the English left. Most of the early superstrate input to Sranan probably came from the southern and southwestern English dialects spoken by a majority of the early planters and indentured laborers who went to the Caribbean, particularly to Barbados, as well as the second language or pidgin varieties spoken by their slaves. After the departure of most of the English, Dutch planters became more involved in plantation management, though their slaves spoke some version of early Sranan. Input from Dutch, especially in the lexicon, must have played some role in the development of Sranan after the colony changed hands. De Kleine (2002), however, argues that Dutch influence was not very prominent in the $17^{\text {th }}$ century due to the relative absence of Dutch speakers. It became stronger in the $18^{\text {th }}$ century with the rise of mixed families who adopted it as their main language.

Slave importations went up significantly after 1675 and Africans came to greatly outnumber Europeans. By 1680, the ratio of Africans to Europeans was 12:1 and by 1720, there were roughly 13,604 Africans and 935 Europeans and in the colony (Postma, 1990:185) - a ration of 14.5 to 1 . The slaves arriving in Suriname during this period came directly from two

4 The English planters who came to Suriname between 1651-1652 came from Barbados. However, some of them had been resident on other Caribbean islands before, such as St Kitts, Nevis and Montserrat (Rens, 1953:14). However, it is not quite clear what their precise regional English origin was. According to Rens (1953), the early population also included a good number of indentured laborers who probably originated from Ireland and Scotland. 
regions in Africa, the Dutch Slave Coast and the Loango area. The former refers to the coastal region of the modern states of Togo and Benin. It is inhabited by speakers of varieties of Gbe. The latter refers to the "region just north of the Zaïre river, i.e., Cabinda, the coastal regions of Congo and Zaire, and southern Gabon." (Arends, 1995:245). It involves speakers of varieties of Kikongo. During the period from 1680 to roughly 1720 speakers of Gbe varieties were clearly dominant. They made up about $70 \%$ of all the slaves brought to Suriname during the early $18^{\text {th }}$ century. Fewer than $20 \%$ were speakers of Kikongo varieties. After 1720, significant numbers of slaves were introduced from the Gold Coast, speaking varieties of Akan and other neighboring Kwa languages. Speakers of Gbe languages also made up a sizeable minority, estimated to have constituted about $20 \%$ between 1720 - 1740. After 1740, slaves imported from the Windward Coast, where languages like Kru and Mande were spoken, came to be in the majority, while speakers of Akan and Gbe varieties declined in numbers (Arends, 1995:240-254).

It is arguable that a full account of substrate influence on the Surinamese creoles would require us to consider all of the West African languages that were introduced to Suriname in the course of the $17^{\text {th }}$ to $19^{\text {th }}$ centuries. However, this volume focuses on the influence of Gbe languages, since both the sociohistorical (Arends, 1995) and linguistic (see below) evidence strongly suggest that speakers of Gbe were the most numerous and influential in the formation period of the early plantation variety $(1670-1700)$ and for some time thereafter. The other African languages which were also present in the formative contact situation, Kikongo and Akan, appear to have contributed much less to the grammar of the Surinamese Plantation Creole, though Kikongo, and to a small extent, Akan and other West African languages contributed to the vocabulary (Arends, 1994; Huttar, 1985; Huttar et al, 2007; Price, 1975).

The historical records do not allow us to accurately determine exactly which Gbe groups were present in what numbers in Suriname from 1660 - 1720. However, research by Pazzi (1979) suggests that the Gbe peoples who were at the time living on the coast between the present-day towns of Cotonou and Lome and roughly 100 miles inland were primarily involved in the slave trade as either slaves or traders. They were the ancestors of the present-day Gen, Phla-Phera and various Ewegbe groups, among others. The Gbe languages can be classified into three groups: Eastern (Fongbe, Gungbe, Phla-Phera, etc.), Central (Ajagbe, etc) and Western (Ewegbe, Gengbe, etc). They display close similarities as well as differences in various areas of their grammars, some of which are discussed in the papers that make up this volume. 


\section{Theories of substrate influence}

We define substrate influence as the result of a process whereby the creators of a creole fully or partially reinterpreted constructions that they encountered from the European input languages, in this case L1, L2 and pidginized varieties of English, according to the principles and patterns of their first language. Once the constructions that emerge from this process of reinterpretation "have been replicated by different speakers, repeated by most of them, and established in the contact situation's new linguistic system (even as a variable feature), they may be characterized genetically as substrate influence." (Mufwene, 1990:2).

While it has become widely accepted among researchers working on creole languages that the first languages of their creators played a role in their formation, there is lack of agreement on the extent of this role, and the precise mechanisms by which structures of the first languages entered the creole. Among the competing theories that have been proposed in this connection are: the relexification hypothesis associated with Lefebvre and her associates (Lefebvre and Lumsden, 1994; Lumsden, 1999; Lefebvre, 1998); Siegel's “transfer” hypothesis (Siegel, 1999, 2000), and Myers-Scotton's “abstract lexical structure model” (Myers-Scotton, 2002). Lefebvre and her associates argue that relexification is a mental process "that allows the language learner to create a new vocabulary of lexical categories (i.e., nouns, verbs, adjectives, prepositions and adverbs) by linking new phonological forms with syntactic and semantic information that is already established in the lexicon of his native language." (Lumsden, 1999:225). Essentially, the creators of creole languages mapped the phonetic shapes of lexemes in the European languages onto the lemmas of corresponding substrate lexemes. This gave rise to new mixed lexical entries that consist of Gbe syntactic and semantic information and European phonetic shapes. Relexification did not just affect content morphemes such as nouns and verbs, but also function morphemes such as tense, mood and aspect markers, prepositions and complementizers. This process also ensured that the structural rules and principles of the substrate are maintained in the creole language because information about such rules and principles is also contained in a word's lexical entry. Differences between substrate and creole structures are accounted for by two other mechanisms, leveling and grammaticalization (Lefebvre 1998).

Siegel $(1999,2010)$ and Wekker (1996) explain the similarities between Creoles and their substrates in terms of transfer in second language acquisition. They argue that the creators of 
creoles establish interlingual identifications between function and lexical morphemes in their L1s and those that they perceive to correspond to them in the superstrate or L2 varieties. Correspondences are established on the basis of positional similarities in a given structure or as the result of (perceived) correspondences in meaning. As a result of this process, the superstrate or L2 lexical item acquires the properties of the substrate one. Siegel (2010) maintains that this process took place when bilingual speakers of a pidgin and a substrate language were expanding the former into a peer group or community language

Myers-Scotton's approach to substrate influence in creole formation is similarly based on the premise that creole lexical entries are reconstituted using input from both substrate and superstrate sources. Myers-Scotton (2002:101) refers to this process as "convergence", and describes it as "a linguistic configuration with all surface morphemes from one language, but part of its abstract lexical structure from another language". To account for this, she proposes her Abstract Level Model, based on psycholinguistic models of language production. Her approach is quite similar to that of the Relexification Hypothesis, except that it appeals to psycholinguistic processes or mechanisms for explanation of the way creole lexical entries and constructions emerge from the splitting and recombining of different aspects of the abstract lexical structures of the languages involved. Winford (2008, to appear) takes a similar approach, which attempts to combine the insights of psycholinguistic models of bilingual language production with those of van Coetsem's model of imposition as mechanism of contact-induced change.

Several of the papers in this volume follow one or the other of these approaches in their investigation of the role of Gbe influence in shaping the grammar of the Surinamese creoles. All of these approaches have in common that they view creole formation as involving processes of natural second language acquisition in somewhat unusual social circumstances. Our own view is based on the same assumption, but we also recognize that other processes also shaped creole grammars, including internally-motivated changes such as grammaticalization, and externallymotivated changes due to continuing contact with other languages. In the case of Suriname, there was continuous contact between the creoles and West African languages and also Dutch, as well as contact among the creoles themselves, all of which led to further developments which we do not explore here.

\section{Methodology for study substrate influence}


Early research on substrate influence tended to match structures that appeared to be divergent from the perspective of European languages with roughly similar ones in West African languages without providing precise sociohistorical evidence that these languages had played a role in the emergence of the creole in question. This often made arguments in favor of substrate influence rather weak. Current research on substrate influence follows a principled methodology laid out by Thomason (1993). She argues that research on creole genesis has to consider both socio-historical and linguistic data and include the following steps. First, researchers must construct a scenario of the creation and development of a creole based on available sociohistorical data concerning the demographic development of the population, its ethnolinguistic origins and patterns of interaction. Second, researchers must identify the languages that played a role in the genesis and development of a creole and at what stages they influenced it based on socio-historical data. Third, the grammars of the main languages that were present during its genesis and development have to be compared in detail with that of the creole. Finally, research on substrate influence should not simply focus on 'divergent' or rare structures since commonly occurring or "unmarked" structures are equally likely to result from substrate influence. In addition, researchers must be aware that substrate influence also overlaps with superstate and universal influence giving rise to multiple causation.

\section{Previous studies of substrate influence in the Surinamese creoles}

Increasing attention has been paid lately to the role of substrate influence in the emergence of creole grammar. Research on the Surinamese creoles in particular has addressed the role of substrate languages in areas such as serial verb constructions (McWhorter, 1992; Migge, 1998), copular-type constructions and adjectival-like predication (Migge, 2000, 2002), predicate reduplication (Migge, 2003), tense, mood and aspect systems (Migge and Winford, 2009; Winford and Migge, 2007; Migge, 2006; Winford, 2006), locative constructions (Essegbey, 2005), certain kinds of complementation (Plag, 1995; Lefebvre and Loranger, 2006; Aboh 2006), focus constructions (Smith, 2006), semantic structures (Essegbey and Ameka, 2007; Huttar et al, 2007; Smith, 1987). These studies have provided many important insights into the relationship between Gbe languages and the Surinamese Creoles. However, as new data on the Gbe languages and the Surinamese Creoles become available new issues have emerged with respect to some areas. Several of the papers in this volume thus revisit syntactic constructions which 
have been investigated in the previous literature, with a view to providing a more complete and principled account of the contribution of substrate influence to their emergence. Other contributions to the volume investigate the role of substrate influence in areas of grammar that have not been explored in previous work. The overall goal of the volume is to provide a richer understanding of the role that substrate input played in the creation of the Surinamese creoles, in the hope that this will contribute toward a better understanding of theories of creole origins in particular, and theories of contact-induced change in general.

\section{This volume}

The volume comprises six papers that focus on a select set of core syntactic and morphosyntactic phenomena, including aspectual and modal categories, relative clauses, the functional categories of the Determiner Phrase, and fact-type complement clauses. The primary question addressed in all the papers is to what extent the Gbe languages contributed to the emergence of these phenomena. Where relevant, the papers also discuss the extent of the similarities and differences among the Surinamese creoles with regard to these aspects of their grammar, and also the extent to which later developments, including contact with Dutch and internal developments, contributed to the evolution of the creole in question.

In "Fact-type complements in Gbe and Surinamese creoles", Bettina Migge and Donald Winford compare fact-type complementation in the Gbe languages with that in the Surinamese creoles in order to determine the level of influence of the former on the latter. Their comparison shows that there is similarity in the range of Complement Taking Predicates (CTP) that take facttype complements in the Gbe languages, Surinamese creoles and English. However, only in former languages is the complementizer homophonous with the verb meaning 'to say'. The discussion is devoted to the non-verbal counterpart of the 'say'-word. In both the Gbe languages and the creoles, this form introduces complements to verbs of cognition and emotion, verbs depicting states of mind, perception verbs, evaluative verbs, verbs that convey modality notions, and subordinate clauses of purpose and result. Several tests of verbhood such as extraction out of the complement, compatibility of the 'say' complementizer with TAM marking, etc, suggest that the item is not verbal in character in either Gbe or the creoles.

Migge and Winford argue that the similarity in function between the complementizer in the Gbe languages and the creoles is not accidental, but is rather due to influence of the former 
on the latter. Although the grammaticalization of the 'say'-verb into a complementizer is widely attested in languages and the core functions of the grammaticalized 'say' verbs are found in other languages, the Gbe and creole forms share a specific set of additional functions, but lack others that are found in other languages. Migge and Winford propose a grammaticalization path for the two language groups which first of all follows a common pathway identified by Chappell (2008) but is then extended to include the function of subordinator, introducing clauses of purpose and consequence. Crucial for this proposal, which the authors discuss at length, is that the grammaticalization of the 'say'-word in the creoles follows a path that is almost identical to that found in the Gbe languages. The similarity is attributed to a process of 'replica grammaticalization' or polysemy copying, as proposed by Heine and Kuteva (2005) (see also Bruyn, 2008).

Although Migge and Winford propose that the complementizer in the creoles is based on that of the Gbe languages, they reject the strict relexification account proposed by Lefebvre and Loranger's (2008) for the complementizers in Saramaccan according to which the complementizer retained the full syntactic and semantic properties of their Gbe counterparts, but were assigned a new phonological form. They argue instead for an account of creole formation that highlights the complex interaction between the different inputs, as well as between different processes of both internally and externally motivated change.

In "A comparison of the nominal structures of Saramaccan, Fongbe and English with reference to Haitian Creole: Implications for a relabelling-based account of creole genesis," Claire Lefebvre compares nominal phrasal elements in Saramaccan with those of Fongbe and English. The elements include the definite determiners, the feature + Number, demonstratives and possessive phrases. She shows that there are lots of parallels between Saramaccan and Fongbe regarding these elements, as opposed to their equivalent in English. For example, regarding their syntax and semantics, Lefebvre shows that definite determiners are anaphoric in Saramaccan and Fongbe, and play an important role in such clause structures as relative clauses, factive clauses, temporal clauses and causal clauses. Moreover, the category of Number shares identical properties in the two languages, while demonstratives display similar combinatory possibilities with other determiners. Lefebvre explains the parallels between the nominal structures in Saramaccan and Fongbe within the general framework of relexification according to which creole lexical items derive their phonological representations from the phonetic strings of the 
superstrate but derive their syntactic and semantic properties from the substrate languages. There are some differences between the two languages though: for instance the definite determiner and plural marker occur in prenominal position in Saramaccan but postnominally in Fongbe. Lefebvre takes this to be due to influence from the ordering of the elements in the English input.

In "Possibility and Necessity Modals in the Gbe and Suriname creoles", James Essegbey, Margot van den Berg, and Marleen van de Vate compare the morphosyntax and semantics of possibility and necessity modals in the Gbe languages with those of Sranan and Saámaka. The origin of TMA plays a major role in the debate on creole origins, and the influence of African languages in this domain has been remarked on since the close of the $19^{\text {th }}$ and the beginning of the $20^{\text {th }}$ centuries (Van Name, 1869; Schuchardt, 1914; and Hesseling, 1905). In the specific case of the Suriname creoles, the influence of the Gbe languages has been amply demonstrated (Migge 2006; Migge and Winford, 2009; Winford and Migge, 2007). However, like some other phenomena reported in other studies in this volume, modality is expressed differently in varieties of Gbe. This raises the question of the relative importance of the different Gbe varieties in the formation of the expression of possibility and necessity modality in the Surinamese Creoles. For instance while Migge (2006) proposes that possibility modality in Eastern Maroon Creoles and Saramaccan is based on that in Gbe varieties like Maxigbe, Migge and Winford (2009) propose that it is derived from Ewegbe. To resolve this issue, among others, Essegbey et al compare not only the form of the possibility and necessity modals but also the temporal interpretations that they give rise to when they occur with verbs in the various languages. This comparison is extended to forms in Portuguese and English, two superstrate languages that were present at various states of the formation of the creoles. Based on differences in the forms of possibility modals as well as the meanings they convey across the Gbe varieties, the authors argue, contra Migge (2006), that Maxigbe-type morphemes could not have served as models for the possibility morpheme in the creoles. Similarly, they argue, contra Migge and Winford (2009), that the Ewegbe form did not form the basis of the expression of all possibility senses. Instead, it influenced the formation of the potential alone. Regarding the meaning of the forms, Essegbey et al note some distinctions in some creoles that can only be attributed to the Gbe languages. Notable among these is the distinction between "inherent" and "acquired" ability which only occurs in the Gbe languages and Saramaccan (and Pamaka). The authors note, however, that Saramaccan speakers give different accounts for this distinction, and that it is gradually 
disappearing from the creoles. The results of the temporal interpretation of the modals yielded mixed results. For example, ability modals in the creoles behaved fully like the Gbe languages and only partially like English. They were not like their counterparts in Portuguese. However, permissive modals behaved completely like their counterparts in Portuguese and only partially like the Gbe languages. It is clear that further research is required to fully clarify this.

In "Relative Clauses in Suriname Creoles and Gbe Languages", George Huttar, Enoch Aboh, and Felix Ameka first compare relativization strategies in Ndyuka with those in Saramaccan, noting similarities and differences. They then compare the strategies in the two creole languages with those in the western and eastern Gbe languages. Specifically the authors look at the syntactic positions of the subject, direct object, and indirect object, and the semantic roles of benefactive, locative, temporal, comitative, instrumental, comparative, and possessor. They also compare relative markers, their other uses, and headless relative clauses. They note that while Ndyuka and Saramaccan exhibit similarities such as the use of gapping as a primary strategy, resumptive pronouns for comitative relativization, and the deletion of instrumental preposition under relativization, they differ in a couple of important ways. One of these is the shape of the relative marker: while Ndyuka uses an invariant form $d i$, the corresponding form in Saramaccan varies according to the number of the head noun. The Gbe languages also manifest similarities as well as differences in their relativization strategies. For example, with regard to the former they all use gapping as the principal strategy and employ a resumptive pronoun in relativization involving nouns with functions such as indirect object and recipient. Differences include the ways they mark plurarity in the relative clause: in some western varieties, the plural morpheme occurs with the relative marker while in other western and all eastern varieties, it occurs on the determiner. After weighing all of these facts and comparing them with equivalent phenomena in other African languages such as Akan and Kabiye, Huttar et al argue that the Gbe languages, despite their minor differences, appear to be a significant source of relativization structure for the creoles. They propose that relativization in Saramaccan was influenced mainly by western Gbe, while that in Ndyuka was influenced by eastern Gbe. They note, however, that the creoles developed relative clauses without relativizers and headless relative clauses independently of the Gbe languages.

In "An account of the stative vs. dynamic split in Saamáka," Marleen van de Vate discusses the temporal interpretation of morphologically unmarked verbs in Saramaccan. Like 
several creoles and the Kwa languages of West Africa, eventive verbs in Saramaccan give rise to a default past interpretation while stative verbs give rise to present interpretation. Most accounts of the past interpretation assume that the event verbs convey perfective aspect, which is why the sentences have past interpretation. van de Vate reframes this approach as the Covert Perfective Analysis (CPA), which she bases on Winford's (2000) analysis of the unmarked verb in Sranan Applying this analysis to Saramaccan, she identifies 3 problems that call it into question. Concluding that the $\mathrm{CPA}$ is inadequate to account for all the interpretations of unmarked verbs in Saramaccan, van de Vate provides an alternative proposal according to which bare verbs are marked by a morphologically null Perfect morpheme. She then proposes a syntactic composition for the morpheme which accounts for the difference in temporal interpretation between bare eventives and statives. She notes in support of her position that in the right discourse context, even stative verbs can have a perfect reading.

In "Done already? A comparison of completive markers in the Gbe languages and Sranan Tongo", Enoch Aboh and Margot van den Berg evaluate the contribution of the Gbe languages to the emergence of the postverbal completive marker kaba in Early Sranan and contemporary Sranan. They note that while the Gbe languages have been cited in studies as having influenced the formation of the completive in Sranan (cf. Winford, 2000, 2006; Bruyn, 2003, Winford and Migge, 2007), the strategies for expressing completive are not similar across all the varieties. Moreover, forms that on the surface appear to be similar have received different analyses for different languages. In order to understand the extent of the influence of Gbe languages on Sranan, the authors undertake a thorough review of the strategies in all the languages. In their discussion of kaba in Early Sranan and contemporary Sranan, Aboh and van den Berg note that it functions as a main verb, a sentence-initial conjunction, and a postverbal element. They find similar uses of clause-final 'finish' in both western Gbe varieties and Fongbe, but they also point to significant differences between eastern and western Gbe languages in the expression of completive and related notions such as 'cessative' and 'perfective'. They find that western Gbe languages more closely resemble early and contemporary Sranan in using "finish" forms as main verbs, postverbal adverbs, and markers of completive aspect and related temporal meanings. Fongbe shows some similarity in these uses of "finish", but also uses a preverbal marker of 'perfect'. Other eastern Gbe varieties like Gungbe do not have the non-verbal uses of "finish", employing a clause-final quantifier rather than an adverb derived from "finish" to express the 
completive. Despite these differences, the authors argue that, underlyingly, the completive structure is the same for all the Gbe languages, in that the elements that convey completive all express event quantification, and have to occur to the right of the structure over which they have scope. They further argue that the Surinamese kaba constructions share the same underlying structure as their Gbe counterparts, and conclude that the latter were the primary influence on the former.

\section{References}

Aboh, E., 2006. Complementation in Saramaccan and Gungbe: The case of C-type modal particles. Natural Language and Linguistic Theory 24 (1), 1-55.

Arends, J., 1994. The African born slave child and creolization (a postscript to the BickertonSingler debate on nativization. Journal of Pidgin and Creole Languages 9 (1), 115-119.

Arends, J., 1995. Demographic factors in the formation of Sranan. In: Arends, J. (ed.), The early stages of creolization, John Benjamins, Amsterdam, pp. 233-285.

Arends, J., 1999. The origin of the Portuguese element in Surinam Creoles. In: Huber, M., and Parkvall, M. (Eds.), Spreading the word: the issues of diffusion among the Atlantic Creoles. University of Westminster Press, London, pp. 195-208.

Arends, J., 2002. The history of the Surinamese creoles I. In Carlin, E., and Arends, J., (Eds.), pp.115-130.

Berg, M., van den. 2000. 'Mi no sal tron tongo' : Early Sranan in court records $1667-1767$. Unpublished MA thesis, University of Nijmegen.

Bruyn, A., 2003. Grammaticalisation, réanalyse et influence substratique: quelques cas du Sranan. In : Kriegel, S. (Ed). Grammaticalisation et réanalyse: approche de la variation créole et francaise, CNRS Editions, Paris, pp. 25-47.

Bruyn, Adrienne. 2008. Grammaticalization in pidgins and creoles. In Kouwenberg, S., and Singler, J., The Handbook of Pidgin and Creole Studies, Blackwell, Oxford, pp. 385-410.

Carlin, E., and Arends, J., 2002. The atlas of the languages of Suriname. KITLV Press, Leiden.

Chappell, H. 2008. Variation in the grammaticalization of complementizers from verba dicendi in Sinitic languages. Linguistic Typology 12, 45-98.

Essegbey, J., 2005. The basic locative construction in Gbe languages and Surinamese Creoles. Journal of Pidgin and Creole Languages 20 (2), 229-267. 
Essegbey, J., and Ameka, F., 2007. "Cut" and "Break" verbs in Sranan. Journal of Pidgin and Creole Languages 22 (1), 37-55.

Heine, B., and Kuteva, T., 2005. Language contact and grammatical change. Cambridge University Press, Cambridge.

Hesseling, D., 1905. Het Negerhollands van der Deense Antillen. A. W. Sijthoff, Leiden.

Hogbergen, W., 1990a. The history of the Surinam maroons. In: Brana-Shute, G. (Ed.), Resistance and rebellion in Suriname: old and new. The College of William and Mary, Williamsburg, pp. 65-102.

Hoogbergen, W., 1990b. The Boni maroon wars in Suriname. E. J. Brill, Leiden.

Huttar, G., 1985. Sources of Ndyuka African vocabulary. De Nieuwe West-Indische Gids 59, 4571.

Huttar, G., Essegbey, J., and Ameka, F., 2007. Gbe and other West African sources of Surinamese creole semantic structures: Implications for creole genesis. Journal of Pidgin and Creole Languages 22 (1), 57-72.

Iatridou, S., Anagnostopoulou E., and Izvorski R., (2003): Observations about the form and meaning of the perfect. In: Alexiadou, A., Rathert, M. and von Stechow, A. (Eds.), Perfect Explorations. Mouton de Gruyter, Berlin, pp. 153-204.

Kleine de, C., 2002. Surinamese Dutch. In Carlin, E., and Arends, J., (Eds.), pp. 209-230.

Lefebvre, C., 1998. Creole genesis and the acquisition of grammar: The case of Haitian creole. Cambridge University Press, Cambridge.

Lefebvre, C., and Loranger, V., 2006. On the properties of Saramaccan fu: Synchronic and diachronic perspectives. Journal of Pidgin and Creole Languages 21 (2), 275-33

Lefebvre, C., and Lumsden, J., 1994. Relexification in Creole genesis. Paper read at the MIT Symposium on the Role of Relexification in Creole Genesis: the case of Haitian Creole.

Lumsden, J., 1999. Language acquisition and creolization. In: DeGraff, M. (Ed.), Language creation and language change: creolization, diachrony and development. MIT Press, Cambridge, Mass., pp. 129-157.

McWhorther, J., 1992. Substratal influence on Saramaccan serial verb constructions. Journal of Pidgin and Creole Languages 7 (1), 1-53. 
Migge, B., 1998. Substrate influence in creole formation: The origin of give-type serial verb constructions in the Surinamese Plantation Creole. Journal of Pidgin and Creole Languages 13 (2), 215-265.

Migge, B., 2000. The origin of property items in the Surinamese Plantation Creole. In: McWhorter, J. (Ed.), Language Change and Language Contact in Pidgins and Creoles. John Benjamins, Amsterdam, pp. 201-234.

Migge, B., 2002. The origin of the copulas $(d / n) a$ and $d e$ in the Eastern Maroon Creole. Diachronica 19 (1), 83-136.

Migge, B., 2003. The origin of predicate reduplication in the Suriname Eastern Maroon Creole. In: Kouwenberg, S. (Ed.), Twice as meaningful. Redublication in Pidgins, Creoles and other Contact Languages, Battlebridge, London, pp. 61-71.

Migge, B., 2006. Tracing the origin of modality in the creoles of Suriname. In: Deumert, A., and Durrleman-Tame, S., (Eds.), Structure and variation in contact languages John Benjamins, Amsterdam, pp. 29-59

Migge, B., and Winford, D., 2009. The origin and development of possibility in the Creoles of Suriname. In Selbach, R., Cardoso, H., and van den Berg, M. (Eds.), Gradual creolization. John Benjamins, Amsterdam, pp. 129-154.

Mufwene, S., 1990. Creoles and universal grammar. Linguistics 28 (4), 783-807.

Myers-Scotton, C., 2002. Contact linguistics: Bilingual encounters and grammatical outcomes. Oxford University Press, New York.

Pazzi, R. 1979. Introduction à l'histoire de l'aire culturelle ajatado. Educes et Documents en Siences Humaines no. 1. Institut National des Sciences de l'Education, Université du Bénin, Lomé, Togo.

Plag, I., 1995. The emergence of taki as a complementizer in Sranan: On substrate influence, universals and gradual creolization. In: Arends, J. (Ed.), The early stages of creolization. John Benjamins, Amsterdam, pp. 113-148.

Postma, J., 1990. The Dutch in the Atlantic slave trade, 1600-1815. Cambridge University Press, Cambridge.

Price, R., 1975. Kikongo and Saramaccan: A reappraisal. Bijdragen tot de Taal-, Land- an Volkenkunde 131, 461-478. 
Rens, L.L.E., 1953. The historical and social background of Surinam's Negro English. Academisch proefschrift. North Holland, Amsterdam.

Schuchardt, H., 1914. Die Sprache der Saramakkaneger in Surinam. Johannes Müller, Amsterdam.

Siegel, J., 1999. Transfer constraints and substrate influence in Melanesian Pidgin. Journal of Pidgin and Creole Languages 14 (1), 1-44.

Siegel, J., 2000. Substrate influence in Hawai'i Creole English. Language in Society 29, 197236.

Siegel, J., 2010. The emergence of Pidgin and Creole languages. Oxford University Press, Oxford.

Smith, N., 1987. The genesis of the creole languages of Suriname. Unpublished PhD thesis. Universiteit van Amsterdam

Smith, N., 2002. The creole languages of Surinam: Past and present. In: Carlin, E., and Arends, J. (Eds.), Language atlas of Surinam. KITLV Press, Leiden, pp. 131-151.

Smith, N., 2006. We-focus in Saramaccan: substrate features or grammaticalization? In: Baker, B., and Syea, A., Changing meanings, changing functions: Papers relating to grammaticalization in contact languages. University of Westminster Press, London, pp. 113-128.

Smith, N., and Haabo, V., 2004. Suriname creoles: phonology. In: Schneider, E. W. (Ed.), The Americas and the Caribbean, Mouton de Gruyter, Berlin, pp. 339-381.

Thoden van Velzen, H. U. E., and Hoogbergen, W., 2011. Een zwarte vrijstaat in Suriname: De Okaanse Samenleving in de 18E Eeuw. KITLV Press, Leiden.

Thomason, S. G., 1993. On identifying the sources of creole structures. In: Mufwene, S., Africanisms in Afro-American language varieties, University of Georgia Press, Athens, GA, pp. $280-295$.

Van Name, A., 1869. Contributions to Creole Grammar. Transactions of the American Philological Association, 1, 123-67.

Voorhoeve, J., and Lichtveld, U., 1975. Creole drum: an anthology of creole literature in Surinam. Yale University Press, New Haven/London. 
Wekker, Herman. 1996. Creolization and the acquisition of English as a second language. In Herman Wekker (ed.) Creole Languages and Language Acquisition, 139-149. Berlin: Mouton de Gruyter.

Westermann, Diedrich. 1965. A Study of the Ewe Language, translated by A.L, Bickford-Smith. New York: Oxford University Press.

Winford, D., 2000. Tense and aspect in Sranan and the Creole Prototype”. In: McWhorter, J. (Ed.), Language change and language contact in Pidgins and Creole. John Benjamins, Amsterdam, pp. 383-442.

Winford, D. 2006. The restructuring of tense/aspect systems in creole formation. In: Deumert A. and Durrleman-Tame (eds.) Structure and variation in language contact. John Benjamins, Amsterdam, pp. 85-110

Winford, D., 2008, Processes of creole formation and related contact-induced language change, Journal of Language Contact, Thema 2, 124-145.

Winford, Donald. To appear. On the unity of contact phenomena: the case for imposition. In Féral C. de and Tosco M. (eds) In and out of Africa; Languages in Question, Louvain-laNeuve, Peeters.

Winford, D., and Migge, B., 2004. Suriname creoles. In: Schneider, E. (Ed.), A handbook of varieties of English: Morphology and syntax. Mouton de Gruyter, Berlin, Vol. 2, pp. 482-516.

Winford, D., and Migge, B., 2007. Substrate influence on the emergence of the TMA systems of the Surinamese creoles. Journal of Pidgin and Creole Languages 22 (1): 73-99. 